medRxiv preprint doi: https://doi.org/10.1101/2021.09.27.21264163; this version posted January 1, 2022. The copyright holder for this preprint (which was not certified by peer review) is the author/funder, who has granted medRxiv a license to display the preprint in It is made available under a CC-BY-NC-ND 4.0 International license .

\title{
Four SARS-CoV-2 vaccines induce quantitatively different antibody responses against SARS-CoV-2 variants
}

Short title: Vaccine antibody responses against SARS-CoV-2 variants

Marit J. van Gils ${ }^{1 *}$, A. H. Ayesha Lavel1 ${ }^{2 \#}$, Karlijn van der Straten ${ }^{1,3 \#}$, Brent Appelman ${ }^{4 \#}$, Ilja Bontjer $^{1}$, Meliawati Poniman ${ }^{1}$, Judith A. Burger ${ }^{1}$, Melissa Oomen ${ }^{1}$, Joey H. Bouhuijs ${ }^{1}$, Lonneke A. van Vught ${ }^{3,6}$, Marleen A. Slim ${ }^{3,6}$, Michiel Schinkel ${ }^{4}$, Elke Wynberg ${ }^{1,5}$, Hugo D.G. van Willigen ${ }^{1}$, Marloes Grobben ${ }^{1}$, Khadija Tejjani $^{1}$, Jonne L. Snitselaar ${ }^{1}$, Tom G. Caniels ${ }^{1}$, Amsterdam UMC COVID-19 S3/HCW study group, Alexander P. J. Vlaar6 ${ }^{6}$, Maria Prins ${ }^{3,5}$, Menno D. de Jong ${ }^{1}$, Godelieve J. de Bree ${ }^{3}$, Jonne J. Sikkens ${ }^{2,4 *}$, Marije K. Bomers ${ }^{2 *}$, Rogier W. Sanders ${ }^{1,7 *}$

${ }^{1}$ Department of Medical Microbiology and Infection Prevention, Amsterdam UMC, University of Amsterdam, Amsterdam Institute for Infection and Immunity, Amsterdam, the Netherlands.

2 Department of Internal Medicine, Amsterdam UMC, Vrije Universiteit Amsterdam, Amsterdam Institute for Infection and Immunity, Amsterdam, the Netherlands.

${ }^{3}$ Department of Internal Medicine, Amsterdam UMC, University of Amsterdam, Amsterdam Institute for Infection and Immunity, Amsterdam, the Netherlands.

4 Center for Experimental and Molecular Medicine, Amsterdam UMC, University of Amsterdam, Amsterdam Institute for Infection and Immunity, Amsterdam, the Netherlands.

${ }^{5}$ Department of Infectious Diseases, Public Health Service of Amsterdam, GGD, Amsterdam, the Netherlands.

${ }^{6}$ Department of Intensive Care Medicine, Amsterdam UMC, University of Amsterdam, Amsterdam Institute for Infection and Immunity, Amsterdam, the Netherlands. NOTE: This preprint reports new research that has not been certified by peer review and should not be used to guide clinical practice. 
medRxiv preprint doi: https://doi.org/10.1101/2021.09.27.21264163; this version posted January 1, 2022. The copyright holder for this preprint (which was not certified by peer review) is the author/funder, who has granted medRxiv a license to display the preprint in It is made available under a CC-BY-NC-ND 4.0 International license .

${ }^{7}$ Department of Microbiology and Immunology, Weill Medical College of Cornell University, New York, USA.

\# These authors contributed equally to this work.

* Correspondence to: r.w.sanders@amsterdamumc.nl, m.bomers@amsterdamumc.nl, j.sikkens@amsterdamumc.nl,m.j.vangils@amsterdamumc.nl

Amsterdam UMC COVID-19 S3/HCW study group:

Diederik van de Beek, Matthijs C. Brouwer, David T.P. Buis, Nora Chekrouni, Niels van Mourik, Sabine E. Olie, Edgar J.G. Peters, Yvo. M. Smulders, W. Joost Wiersinga. 
medRxiv preprint doi: https://doi.org/10.1101/2021.09.27.21264163; this version posted January 1, 2022. The copyright holder for this preprint (which was not certified by peer review) is the author/funder, who has granted medRxiv a license to display the preprint in It is made available under a CC-BY-NC-ND 4.0 International license .

\begin{abstract}
Emerging and future SARS-CoV-2 variants may jeopardize the effectiveness of vaccination campaigns. We performed a head-to-head comparison of the ability of sera from individuals vaccinated with either one of four vaccines (BNT162b2, mRNA-1273, AZD1222 or Ad26.COV2.S) to recognize and neutralize SARS-CoV-2 variants of concern (VOCs; Alpha, Beta, Gamma, Delta and Omicron). Four weeks after completing the vaccination series, SARSCoV-2 wild-type neutralizing antibody titers were highest in recipients of BNT162b2 and mRNA-1273 (median titers of 1891 and 3061, respectively), and substantially lower in those vaccinated with the adenovirus vector-based vaccines AZD1222 and Ad26.COV2.S (median titers of 241 and 119, respectively). VOCs neutralization was reduced in all vaccine groups, with the largest ( 9 to 80 -fold) reduction in neutralization being observed against the Omicron variant. Overall, the mRNA vaccines appear superior to adenovirus vector-based vaccines in inducing neutralizing antibodies against VOCs four weeks after the second vaccination.
\end{abstract}

\title{
Keywords
}

SARS-CoV-2, vaccines, variants, serology, antibody responses 
medRxiv preprint doi: https://doi.org/10.1101/2021.09.27.21264163; this version posted January 1, 2022. The copyright holder for this preprint (which was not certified by peer review) is the author/funder, who has granted medRxiv a license to display the preprint in It is made available under a CC-BY-NC-ND 4.0 International license .

\section{Introduction}

As of December 2021, the coronavirus disease 2019 (COVID-19) pandemic has caused over 275 million confirmed infections and over 5.3 million reported deaths ${ }^{1}$, calling for strong interventions. A number of vaccines have been developed that proved efficacious in preventing severe acute respiratory syndrome coronavirus 2 (SARS-CoV-2) infection, the causative agent of COVID-19, and/or severe disease from infection, providing hope that we can halt this pandemic. Three vaccines, i.e. those developed by Pfizer-BioNTech (BNT162b2/Comirnaty), Moderna (mRNA-1273/Spikevax) and J\&J/Janssen (Ad26.COV2.S), have been approved (for emergency use) in the United States by the FDA, while the EMA in the European Union has additionally approved (for emergency use) a fourth vaccine from Oxford/AstraZeneca (AZD1222/Vaxzevria), and very recently a fifth from Novavax (NVX-CoV2372/Nuvaxovid). Early efficacy trials showed that the mRNA vaccines BNT162b2 and mRNA-1273 had high efficacy ( $>90 \%$ ) against symptomatic infection, whereas the adenovirus vector-based vaccines AZD1222 and Ad26.COV2.S resulted in lower vaccine efficacy (60-70\%) against symptomatic infection $^{2-5}$. Efficacy waned somewhat over time for all vaccines ${ }^{6}$. However, all vaccines were extremely effective at preventing severe disease. Neutralizing antibodies proved to be a very strong correlate of protection ${ }^{7-9}$. So far, over 8 billion COVID-19 vaccine doses have already been administered worldwide ${ }^{10}$.

Since the start of the pandemic, SARS-CoV-2 has diversified considerably, both genetically and antigenically. Currently, five virus lineages have been designated as a variant of concern (VOC) by the WHO due to, among others, suspected increased transmissibility or virulence: Alpha (B.1.1.7/20I/N501Y.V1), Beta (B.1.351/20H/N501Y.V2), Gamma (B.1.1.28.P1/P.1/20J/N501Y.V3), Delta (B.1.617.2/21A) and Omicron (B.1.1.529/21K/BA.1). All five VOCs have spread globally, with the Delta variant currently being the dominant variant in many countries, but Omicron is replacing Delta rapidly ${ }^{11}$. In addition to the five VOCs, the 
medRxiv preprint doi: https://doi.org/10.1101/2021.09.27.21264163; this version posted January 1, 2022. The copyright holder for this preprint (which was not certified by peer review) is the author/funder, who has granted medRxiv a license to display the preprint in It is made available under a CC-BY-NC-ND 4.0 International license .

WHO has defined a number of variants of interest (VOIs) that should be monitored closely as well. From studies on monoclonal antibodies, including ones developed for therapeutic application in COVID-19, it is known that these can lose neutralization potency against the VOCs and VOIs, in particular those targeting the receptor binding motive (RBM) on the SARSCoV-2 spike (S) protein ${ }^{12}$. The most relevant mutations for loss of neutralization of Alpha, Beta, Gamm and Delta include E484K, K417T/N and L452R/Q in the receptor binding domain (RBD) and $\Delta 69-70$ and $\Delta 242-244$ in the N-terminal domain (NTD), while Omicron has many more mutations: 32 in S, including 15 in RBD. Considering the pandemic is still ongoing, it is important to know how the different vaccines perform against the different SARS-CoV-2 variants.

In field trials, several vaccines proved less efficacious against VOCs, in particular the Beta $^{13-20}$. In fact, the Oxford/AstraZeneca vaccine was virtually ineffective in preventing symptomatic COVID-19 in South-Africa, where the Beta variant dominated during the trial ${ }^{21}$. In England, reduced effectiveness against symptomatic COVID-19 was observed with the Delta variant compared to the Alpha variant ${ }^{22}$, in particular after a single vaccine dose. The emerging data indicates that vaccine efficacy is further and substantially reduced against Omicron, necessitating booster immunizations ${ }^{23-25}$. In line with these observations, VOCs were shown to be less sensitive to neutralizing antibodies induced by infection or vaccination. Antibody responses are generally sufficient to neutralize the Alpha variant to similar levels as the original Wuhan strain in mRNA vaccine recipients and in convalescent individuals. However, the Beta, Gamma, Delta and Omicron variants showed on average an 9 fold, 4-fold, 4-fold and 20 to 40-fold reduced sensitivity respectively to neutralization by sera from convalescent patients as well as from vaccine recipients ${ }^{19,24-25}$.

Although previous studies have provided valuable initial insights in the sensitivity of VOCs to neutralization induced by infection or vaccination, few studies have directly compared 
medRxiv preprint doi: https://doi.org/10.1101/2021.09.27.21264163; this version posted January 1, 2022. The copyright holder for this preprint (which was not certified by peer review) is the author/funder, who has granted medRxiv a license to display the preprint in It is made available under a CC-BY-NC-ND 4.0 International license .

the ability of humoral responses induced by the four different vaccines to cope with VOCs. Previous studies have used diverse serological assays, mainly focused on one or two vaccines, or used regression models to combine studies, complicating direct comparisons. Here, we present a head-to-head comparison of the neutralizing activity against all five VOCs in the serum of individuals who received the BNT162b2, mRNA-1273, AZD1222 or Ad.COV2.S vaccine.

\section{Results}

\section{Binding and neutralizing antibody responses after complete vaccination regimens}

In a direct head-to-head comparison, using the same assays, we assessed the ability of four FDA and/or EMA approved SARS-CoV-2 vaccines to induce humoral immune responses in humans. From the S3 cohort, which consists of Amsterdam UMC health care workers $(\mathrm{HCWs})^{26}$, we included SARS-CoV-2 naive individuals who completed BNT162b2 $(\mathrm{n}=50)$, mRNA-1273 $(n=40)$, AZD1222 $(n=41)$ or Ad26.COV2.S vaccination $(n=13$; Table S1). Although the four vaccine groups were fairly similar in composition; $62-87 \%$ female with the majority between 35-60 years old (Table 1), the AZD1222 group mostly consists of individuals over 60 years of age, because the Dutch government restricted the use of AZD1222 to this age group due to safety concerns. Furthermore, the Ad26.COV2.S group included fewer individuals because the Dutch government temporarily restricted its use because of similar reasons $^{27}$. For vaccinees who received the BNT162b2, mRNA-1273 and AZD122 vaccines, samples were taken three weeks after the first vaccination and four weeks after the second vaccination (Fig. 1A). As the Ad26.COV2.S vaccine uses a single-dose regime, vaccine recipients were sampled approximately five and eight weeks after the single-dose vaccination.

We first assessed S protein binding titers in vaccinee sera after complete vaccination in a custom luminex assay against the wild-type (WT) S protein from the Wuhan Hu-1 virus 
medRxiv preprint doi: https://doi.org/10.1101/2021.09.27.21264163; this version posted January 1, 2022. The copyright holder for this preprint (which was not certified by peer review) is the author/funder, who has granted medRxiv a license to display the preprint in It is made available under a CC-BY-NC-ND 4.0 International license .

(GenBank: MN908947.3) isolated in December 2019, i.e. the same S protein sequence as was used in the four vaccines ${ }^{28}$. Overall, the antibody responses against the S protein were relatively homogeneous within each group, showing larger intergroup than intragroup difference, with only one Ad26.COV2.S recipient having binding titers below the limit of detection after complete vaccination (Fig. 1B, Table S2). Antibody responses in fully vaccinated mRNA-1273 and BNT162b2 recipients were comparable with convalescent individuals 4-6 weeks after symptom onset (COSCA study, $\mathrm{n}=68$ ) (median MFI titers of 1482 and 1257 versus 1382, respectively), but the responses of AZD1222 and Ad26.COV2.S recipients were substantially (17 to 29-fold) lower (median MFI of 74 and 52, respectively).

Next, we tested the neutralizing activity of vaccinee sera using a lentiviral-based pseudovirus assay of the SARS-CoV-2 D614G (B.1) variant (Fig. 1C, Table S2), which has been shown to strongly correlate with authentic virus neutralization assay ${ }^{29}$. We detected the highest neutralization activity in recipients of mRNA-1273 and BNT162b2 (median ID $_{50}$ titers of 3061 and 1891, respectively), and approximately an order of magnitude lower activity in those vaccinated with the adenovirus vector-based vaccines AZD1222 and Ad26.COV2.S (median ID 50 titers of 241 and 119, respectively), with 1/50 BNT162b2, 7/30 AZD1222 and 6/13 Ad26.COV2.S recipients having undetectable neutralization activity (half-maximal neutralization titer, $\mathrm{ID}_{50}<100$ ) (Fig. $1 \mathrm{C}$, Table S2). The differences in humoral immune responses between the groups following vaccination are consistent with the observed differences in the efficacy of these vaccines and in agreement with the observations that neutralizing antibodies are a strong correlate of protection ${ }^{19,30,31}$.

\section{Binding and neutralizing antibody responses after one vaccination}

We also assessed the responses after one vaccination with each of the four vaccines. First, we wished to directly compare the single-dose of Ad26.COV2.S with one dose of each 
medRxiv preprint doi: https://doi.org/10.1101/2021.09.27.21264163; this version posted January 1, 2022. The copyright holder for this preprint (which was not certified by peer review) is the author/funder, who has granted medRxiv a license to display the preprint in It is made available under a CC-BY-NC-ND 4.0 International license .

of the other three vaccines. Second, we wanted to gauge the level of humoral immunity after partial vaccination, which is relevant when vaccinating during an infection wave and/or when considering to postpone the second vaccination.

All BNT162b2 and mRNA-1273 recipients had detectable antibody binding titers against S after one vaccination, while 5 out of 42 AZD1222 and 1 of 13 Ad26.COV2.S recipients did not (Fig. 1B). The binding antibody titers were highest for the mRNA vaccine groups with mRNA-1273 recipients (median titer of 351) exceeding not only the level after one vaccination of the three other vaccines (median of 135, 27 and 52 for BNT162b2, AZD1222 and Ad26.COV2.S, respectively), but also the binding titers after two doses of AZD1222 (median titer 74). The neutralizing antibody levels after one dose were low in all cases (median titers of $<100$ for BNT162b2 and AZD1222, 119 for Ad26.COV2.S and 300 for mRNA-1273) with only 19 of 45 (42\%) BNT162b2, 13 of 35 (37\%) AZD1222, 7 of 13 (54\%) Ad26.COV2.S and 26 of 31 (84\%) mRNA-1273 having detectable neutralization ( ID $\left._{50}>100\right)$ (Fig. 1C). Interestingly, eight weeks after the single Ad26.COV2.S vaccination the neutralization titers were slightly increased compared to the five week samples (median ID $_{50}$ of 168 versus 119 ), and two additional recipients showed detectable neutralization indicative of some maturation of the antibody response.

\section{Binding and neutralizing antibody responses against VOCs}

We generated pre-fusion stabilized S proteins from four VOCs (i.e. Alpha/B.1.1.7, Beta/B.1.351, Gamma/P.1 and Delta/B.1.617.2; Table S3) for use in our custom luminex assay. After full vaccination, the binding antibody responses against VOCs S proteins were similar to those against WT S protein (Fig. S1A, Table S2) as was the ranking of the different vaccines. Thus, mRNA vaccine recipients had higher binding responses compared to adenovirus vectorbased vaccine recipients for all VOCs. 
medRxiv preprint doi: https://doi.org/10.1101/2021.09.27.21264163; this version posted January 1, 2022. The copyright holder for this preprint (which was not certified by peer review) is the author/funder, who has granted medRxiv a license to display the preprint in It is made available under a CC-BY-NC-ND 4.0 International license .

We next tested the neutralizing activity of the vaccine sera against the five VOCs (Fig. 2A-B, Table S2). As emerging data indicates that neutralization against Omicron is substantially reduced, we tested the sera at lower dilutions against this VOC. The neutralizing titers against the VOCs were highest in the mRNA recipients (median ID 50 of 1141 (Alpha), 482 (Beta), 1067 (Gamma), 694 (Delta), <20 Omicron for BNT162b2 recipients and 2388 (Alpha), 625 (Beta), 2014 (Gamma), 1520 (Delta), 200 (Omicron) for mRNA-1273 recipients), compared to the AZD1222 recipients (median ID $_{50}$ of 143 (Alpha), $<100$ (Beta), $<100$ (Gamma), $<100$ (Delta), $<20$ (Omicron)), and the Ad26.COV2.S recipients (median ID $_{50}$ of $<100$ (Alpha), <100 (Beta), <100 (Gamma), <100 (Delta), <20 (Omicron); Fig. 2A). The fold reduction in VOCs neutralization compared to wild-type was similar for all groups and consistent with previous reports for convalescent sera and vaccine sera showing the largest decrease of neutralization capacity against the Omicron variant ( 9 to 80 fold; Fig. S1B), followed in order by Beta, Delta, Gamma and Alpha ${ }^{19,20,32-37}$. However, the decrease of neutralization for the Omicron variant was lower for the mRNA-1273 recipients compared to the BNT162b2 recipients, which resulted in significantly higher Omicron neutralization titers for mRNA-1273 recipients compared to the other groups (Fig. 2B). Overall, binding and neutralizing antibody responses correlated very well $(\mathrm{r}=0.7995, \mathrm{p}<0.0001$ for wild-type and $\mathrm{r}=0.8093, \mathrm{p}<0.0001$ for Beta; Fig. S2). Antibody binding titers against the VOCs S proteins on the other hand were largely unaffected, suggesting that neutralizing antibodies form a minority among all antibodies.

Importantly, the proportion of individuals who did not show detectable VOC neutralization was substantial in the AZD1222 and Ad26.COV2.S recipients (8/30 nonresponders for Alpha, 26/30 for Beta, 16/30 for Gamma, 27/30 for Delta, and 30/30 when considering $<100$ and 26/30 when considering $<20$ for Omicron of the AZD1222 recipients and 8/13 non-responders (Alpha), 12/13 (Beta), 12/13 (Gamma), 9/13 (Delta), and 13/13 (<20; 
medRxiv preprint doi: https://doi.org/10.1101/2021.09.27.21264163; this version posted January 1, 2022. The copyright holder for this preprint (which was not certified by peer review) is the author/funder, who has granted medRxiv a license to display the preprint in It is made available under a CC-BY-NC-ND 4.0 International license .

Omicron) of the Ad26.COV2.S recipients, versus 1/50 non-responders (Alpha), 2/50 (Beta), 1/50 (Gamma), 2/50 (Delta), and 46/50 $(<100)$ or 29/50 $(<20$; Omicron) of the BNT162b2 recipients and 1/30 non-responders (Alpha), 2/30 (Beta), 0/30 (Gamma), 0/30 (Delta), and 9/30 $(<100)$ or $0 / 30(<20$; Omicron) of the mRNA-1273 recipients) (Fig. 2A). Overall, the results show that the mRNA vaccines induce substantial levels of neutralizing antibodies against currently defined VOCs, with the exception of Omicron, while the adenovirus vector-based vaccines are much less efficient in doing so against all VOCs. The median neutralization titers from our study correlated strongly with the levels of protection from symptomatic infection by the respective strains as obtained from vaccine efficacy trials $(r=0.9321, p<0.001$; Fig. $2 \mathrm{C}$, $\mathrm{S} 3 \mathrm{~A})^{3,20,33-40}$, reinforcing the association between neutralization and protection from infection $^{19,30,31}$.

\section{Neutralizing antibody responses against VOI}

Finally, we evaluated neutralization of a number of variants of interest (VOI) and other SARS-CoV-2 variants, including Kappa (B.1.617.1), Lambda (C.37), Epsilon (B.1.429), Iota (B.1.526), Zeta (B.1.1.28.P.2/P.2) ${ }^{41}$, as well as subvariants within the Alpha and Beta VOC lineages (Table S3). As sera quantities were limited, we tested these viruses against pooled sera from each vaccine group, as well as pooled sera from two convalescent cohorts, the COSCA and RECOVERED ${ }^{42,43}$. Since most Ad26.COV2.S recipients had undetectable neutralizing ability against VOC's, these sera were not included in this analysis.

We also included the five VOCs in this analysis and found that the neutralization $\mathrm{ID}_{50}$ values obtained with the pooled sera were highly concordant with the median $\mathrm{ID}_{50}$ values of the individual sera, indicating that the pooling of sera yields representable results. The set of pooled sera had diverse neutralization titers against the VOCs and VOIs (Fig. 3). In particular, the Beta, Omicron and Kappa variants showed reduced sensitivity to neutralization, confirming 
medRxiv preprint doi: https://doi.org/10.1101/2021.09.27.21264163; this version posted January 1, 2022. The copyright holder for this preprint (which was not certified by peer review) is the author/funder, who has granted medRxiv a license to display the preprint in It is made available under a CC-BY-NC-ND 4.0 International license .

previously observed fold reductions (Fig. S3B) ${ }^{19,44}$. The rank order between the different vaccines was consistent between the various VOCs and VOIs. The additional E484K mutation in the Alpha variant caused an additional 2.8-fold reduction in neutralization for all pools, corroborating the impact of this single RBD mutation on neutralization. The Beta, Gamma, Iota and Zeta variants have this mutation, while the Kappa variant has the E484Q and Omicron the E484A mutation, contributing to their reduced sensitivity. The differences observed between these VOCs and VOIs indicate that other mutations in addition to E484K/Q/A, such as the $\mathrm{K} 417 \mathrm{~T} / \mathrm{N}$ and $\mathrm{L} 452 \mathrm{R} / \mathrm{Q}$ in the RBD and mutations in the N-Terminal Domain (NTD), contribute to decreased sensitivity to neutralization.

\section{Discussion}

Current and future SARS-CoV-2 variants could potentially jeopardize the effectiveness of vaccines in curbing the pandemic by escaping vaccine-induced immune responses. We present a direct comparison of the ability of four approved SARS-CoV-2 vaccines to induce neutralizing antibodies against VOCs, revealing that the mRNA vaccines are profoundly superior to the adenovirus vector-based vaccines at inducing neutralizing antibodies. We further show that the antibodies in SARS-CoV-2 vaccine recipients, sampled around the expected peak of their immunity, showed a marked decrease in neutralization potency against the VOCs, especially the Omicron variant. When neutralization activity against the original strain was limited, as observed after AZD1222 or Ad26.COV2.S vaccination, the capability to potently neutralize different variants is severely diminished. The implication is that individuals receiving one of the adenovirus vector-based vaccines are more vulnerable to infection with the VOCs, which is consistent with the lower efficacy of these vaccines against symptomatic infection with VOCs compared to the mRNA vaccines, although all vaccines are highly effective at preventing severe disease by $\operatorname{VOCs}^{3,20,33-40}$. 
medRxiv preprint doi: https://doi.org/10.1101/2021.09.27.21264163; this version posted January 1, 2022. The copyright holder for this preprint (which was not certified by peer review) is the author/funder, who has granted medRxiv a license to display the preprint in It is made available under a CC-BY-NC-ND 4.0 International license .

The differences between mRNA and adenovirus vector-based vaccines might have several reasons. First, Ad26.COV.2 was only used as a single dose whilst a second boost immunization might very well enhance its ability to induce neutralizing antibodies. A recent study suggests that this might indeed be the case ${ }^{45}$. This argument does not hold for AZD1222 as the increase of the antibody levels after the second dose was substantially less pronounced in the AZD1222 recipients compared to the mRNA vaccine recipients. One difference between AZD1222 and the Ad26.COV.S, mRNA-1273 and BNT162b2 vaccines is that it encodes for an unmodified S protein, while the other three vaccines encode for a proline-stabilized version of $\mathrm{S}$, which might be more conducive for the induction of neutralizing antibodies ${ }^{46}$. Other platform-intrinsic factors might also play a role, such as differences in $\mathrm{S}$ expression levels and/or the duration of S expression.

Our neutralization results correlated remarkably well with the efficacy of the four vaccines against VOCs $(r=0.9321, \mathrm{p}<0.0001)$ and reinforce the reports that neutralizing antibodies are a strong correlate of protection ${ }^{19,30,31}$. However, strong neutralizing antibody responses do not alone account for the protection by current vaccines ${ }^{47}$. While neutralizing antibody levels were low and often undetectable in our assay after full vaccination with the adenovirus vector-based vaccines in comparison to mRNA vaccines, especially against the VOC, the vaccines still show substantial vaccine efficacy against symptomatic infection and severe disease $(>60 \%)$, albeit less than the mRNA vaccines ${ }^{3,20,33-40}$. This strongly suggests that other immune components play important roles. These include low levels of neutralizing antibodies $\left(\mathrm{ID}_{50}<100\right), \mathrm{T}$ cells, and possibly non-neutralizing antibodies with effector functions ${ }^{48-51}$. Furthermore, memory B cell responses are likely to play a role, in particular in protection against severe disease $\mathrm{e}^{52,53}$. An additional vaccine administration to AZD1222 and Ad26.COV.2 recipients, either with the same vaccine or with an mRNA vaccine, could further boost this protection. Recent studies indeed suggest that booster vaccines and heterologous 
medRxiv preprint doi: https://doi.org/10.1101/2021.09.27.21264163; this version posted January 1, 2022. The copyright holder for this preprint (which was not certified by peer review) is the author/funder, who has granted medRxiv a license to display the preprint in It is made available under a CC-BY-NC-ND 4.0 International license .

adenovirus prime mRNA boost regimens might be superior to adenovirus only or mRNA only $^{54,55}$.

After one vaccine dose, we observed higher neutralization titers for mRNA-1273 recipients compared to the individuals receiving BNT162b2. Another study also reported that mRNA-1273 was slightly more efficient at inducing neutralizing antibodies compared to BNT162b2 $2^{56}$. Furthermore, mRNA-1273 induced significantly higher neutralizing antibody titers against Omicron than BNT162b2 (median 200 versus $<20$ respectively, $\mathrm{p}<0.0001$ ). One explanation could be the higher mRNA dose in the mRNA-1273 vaccine (100 $\mu \mathrm{g}$ versus $30 \mu \mathrm{g}$ in the BNT162b2 vaccine). This might also explain the reported limited efficacy of the Curevac vaccine $(\mathrm{CVnCoV})$, which contained only $12 \mu \mathrm{g}$ of mRNA, although the instability of the mRNA due to the use of unmodified bases might have contributed to this as well ${ }^{57}$.

Our results, as well as many previous studies, identify the main culprits among the mutations present in VOCs and VOIs for reducing neutralization sensitivity. As RBD antibodies dominate the neutralizing antibody response, RBD mutations proved critical. E484K/A (present in Beta, Gamma and Omicron) abrogates sensitivity to a number of RBD antibodies, while L452R (present in Delta) and K417N/T (present in Beta, Gamma and Omicron) affect other subsets of RBD antibodies ${ }^{44,58,59}$. Several therapeutic antibodies currently in use for COVID-19 treatment are affected by these mutations and have reduced activity against VOCs ${ }^{60}$. The accumulation of these mutations, as well as others, in Omicron and in the context of a heavily mutated lab-built version of the Delta variant, renders them profoundly more resistant to neutralization ${ }^{61}$.

There are several limitations of our study. First, our study includes substantially more female than male participants, reflecting the gender distribution among HCW at our institute. Second, the age distribution in the four groups is not identical. In particular, the AZD1222 group is considerably older as a consequence of restrictive use of the AZD1222 vaccine in 
medRxiv preprint doi: https://doi.org/10.1101/2021.09.27.21264163; this version posted January 1, 2022. The copyright holder for this preprint (which was not certified by peer review) is the author/funder, who has granted medRxiv a license to display the preprint in It is made available under a CC-BY-NC-ND 4.0 International license .

individuals aged 60-64 years in the Netherlands. As immune responses tend to become weaker with higher age, this is a relevant factor when considering the weaker responses in the AZD1222 group. Finally, the samples we tested were taken at the expected peak of immunity. It will be relevant to study the durability of the neutralizing antibody responses after vaccination with each of these vaccines. Some studies suggest that immunity induced by adenovirus vaccines might be more durable than immunity from mRNA vaccines ${ }^{19,62}$.

We have analyzed known VOCs and many VOIs. While we cannot predict how our results apply to future variants, the data with Omicron reveal how antigenic drift can substantially impact the extent to which vaccine-induced responses can cross-neutralize new antigenic variants. Current VOCs up to Omicron were probably selected based on increased fitness and/or transmissibility, while Omicron and future variants may very well be selected based on escape from immunity when more and more people are vaccinated or have experienced COVD-19. Such escape variants are more resistant to neutralizing antibodies induced by current vaccines and should prompt vaccine updates based on circulating variants. However, while circulating antibodies might be unable to neutralize such emerging viruses, memory B cells are still likely to recognize them and undergo new rounds of affinity maturation, resulting in new neutralizing antibodies that should kick-in in time to prevent severe disease after infection.

\section{Materials \& methods}

\section{Study design}

Since March 2020 we followed a cohort of HCW in the Amsterdam University Medical Centers, consisting of two tertiary care hospitals ${ }^{63}$. Participants underwent frequent phlebotomies to determine seroconversion against SARS-CoV-2, measured by total Ig against S1-RBD using enzyme-linked immunosorbent assay (Wantai ELISA). In January 2021 
medRxiv preprint doi: https://doi.org/10.1101/2021.09.27.21264163; this version posted January 1, 2022. The copyright holder for this preprint (which was not certified by peer review) is the author/funder, who has granted medRxiv a license to display the preprint in It is made available under a CC-BY-NC-ND 4.0 International license .

seronegative $\mathrm{HCW}$ who received two doses of BNT162b2 with an interval of three weeks were included. From March till May 2021 another group of HCW was included who received the first dose of either mRNA-1273 or AZD1222, or a single dose Ad.26CoV2.S. The second dose of mRNA-1273 or AZD1222 was administered four weeks or six to twelve weeks after the first, respectively (Fig. 1A). Blood samples were taken approximately three weeks after the first vaccine with BNT162b2, mRNA-1273 and AZD1222 and four weeks after the second vaccine. In the case of vaccination with Ad.26CoV2.S, blood samples were taken approximately four to five and eight weeks after vaccination (Fig. 1A). Preferably a blood sample was taken within days before the first vaccine was administered.

Participants in the COSCA cohort were included from March 2020 till the end of January 2021, with the wild-type and D614G variant being the dominant circulating strains ${ }^{64}$. These include hospitalized and non-hospitalized participants and serum was obtained four to six weeks after symptom onset ${ }^{43}$. A serum pool was created from COSCA samples of 68 participants. Another serum pool was created from sera collected in the RECoVERED cohort ${ }^{65}$. In total, 251 RECoVERED serum samples were used, obtained up to seven months post start of symptoms (median of 3 months) from participants who experienced mild, moderate or severe COVID-19. The S3 study, the COSCA study and the RECoVERED study were approved by the medical ethical review board of the Amsterdam University Medical Centers (NL73478.029.20, NL73281.018.20 and NL73759.018.20, respectively). All participants provided written informed consent.

\section{Protein design}

The S constructs contained the following mutations compared to the WT variant (Wuhan $\mathrm{Hu}-$ 1; GenBank: MN908947.3): deletion ( $\Delta$ ) of H69, V70 and Y144, N501Y, A570D, D614G, P681H, T716I, S982A and D1118H in B.1.1.7 (Alpha); L18F, D80A, D215G, L242H, R246I, 
medRxiv preprint doi: https://doi.org/10.1101/2021.09.27.21264163; this version posted January 1, 2022. The copyright holder for this preprint (which was not certified by peer review) is the author/funder, who has granted medRxiv a license to display the preprint in It is made available under a CC-BY-NC-ND 4.0 International license .

K417N, E484K, N501Y, D614G and A701V in B.1.351 (Beta); L18F, T20N, P26S, D138Y, R190S, K417T, E484K, N501Y, D614G, H655Y and T1027I in P.1 (Gamma); T19R, K77T, G142D, L452R, T478K, D614G, and D950N in B.1.617.2 (Delta). They were ordered as gBlock gene fragments (Integrated DNA Technologies) and cloned in a pPPI4 expression vector containing a hexahistidine (his) tag with Gibson Assembly (ThermoFisher) ${ }^{43}$. All S constructs were verified by Sanger sequencing and subsequently produced in HEK293F cells (ThermoFisher) and purified as previously described ${ }^{43}$.

\section{Protein coupling to Luminex beads}

To measure the binding of IgG to the spike proteins of different VOCs, we covalently coupled pre-fusion stabilized spike proteins to Luminex Magplex beads using a two-step carbodiimide reaction as previously described ${ }^{66}$. In short, Luminex Magplex beads (Luminex) were washed with $100 \mathrm{mM}$ monobasic sodium phosphate $\mathrm{pH} 6.2$ and activated by addition of Sulfo-NHydroxysulfosuccinimide (Thermo Fisher Scientific) and 1-Ethyl-3-(3-dimethylaminopropyl) carbodiimide (Thermo Fisher Scientific) and incubated for 30 minutes on a rotator at room temperature. After washing the activated beads three times with $50 \mathrm{mM}$ MES pH 5.0, the spike proteins were added in ratio of $75 \mu \mathrm{g}$ protein to 12.5 million beads and incubated for three hours on a rotator at room temperature. To block the beads for aspecific binding, we incubated the beads for 30 minutes with PBS containing 2\% BSA, 3\% fetal calf serum and $0.02 \%$ Tween20 at $\mathrm{pH}$ 7.0. Finally, the beads were washed and stored at $4^{\circ} \mathrm{C}$ in PBS containing $0.05 \%$ sodium azide.

\section{Luminex assays}

Optimization experiments determined the optimal concentration of the sera for studying the humoral vaccination response to be 100.000 -fold dilution. As previously described ${ }^{67}, 50 \mu \mathrm{L}$ of 
medRxiv preprint doi: https://doi.org/10.1101/2021.09.27.21264163; this version posted January 1, 2022. The copyright holder for this preprint (which was not certified by peer review) is the author/funder, who has granted medRxiv a license to display the preprint in It is made available under a CC-BY-NC-ND 4.0 International license .

a bead mixture containing all different spike proteins in a concentration of 20 beads per $\mu \mathrm{L}$ were added to $50 \mu \mathrm{L}$ of diluted serum and incubated overnight on a rotator at $4^{\circ} \mathrm{C}$. The next day, plates were washed with TBS containing $0.05 \%$ Tween-20 (TBST) and resuspended in 50 $\mu \mathrm{L}$ of Goat-anti-human IgG-PE (Southern Biotech). After 2 hours of incubation on a rotator at room temperature, the beads were washed with TBST and resuspended in $70 \mu \mathrm{L}$ Magpix drive fluid (Luminex). Read-out of the plates was performed on a Magpix (Luminex). The binding of antibodies is expressed as the Median Fluorescence Intensity (MFI) of approximately 50 to 100 beads per well. MFI values are corrected for background signals by subtracting the MFI of wells containing only buffer and beads. To confirm assay performance, a titration of serum of one convalescent COVID-19 patient as well as positive and negative controls were included on each plate. In addition, 15 to $20 \%$ of samples of each run were replicated to confirm the results.

\section{Pseudovirus construction}

The WT, D614G, Alpha, Alpha E484K, Beta, Gamma and Omicron pseudovirus S constructs were ordered as gBlock gene fragments (Integrated DNA Technologies) and cloned using SacI and ApaI in the pCR3 SARS-CoV-2-S $\mathrm{S}_{\Delta 19}$ expression plasmid ${ }^{68}$ using Gibson Assembly (ThermoFisher). Pseudovirus S expression constructs for Delta and Kappa were provided by Dr. Beatrice Hahn, while those for Beta $\Delta 242-244$, Lambda, Epsilon, Iota and Zeta were provided by Drs. Paul Bieniasz and Theodora Hatziioannou. All constructs were verified by Sanger sequencing, mutations for the VOCs and VOIs are indicated in Table S3. Pseudoviruses were produced by co-transfecting the SARS-CoV-2-S expression plasmid with the pHIV-1 $1_{\mathrm{NL} 43}$ $\triangle$ Env-NanoLuc reporter virus plasmid in HEK293T cells (ATCC, CRL-11268), as previously described ${ }^{68}$. Cell supernatant containing the pseudovirus was harvested 48 hours post transfection and stored at $-80^{\circ} \mathrm{C}$ until further use. 
medRxiv preprint doi: https://doi.org/10.1101/2021.09.27.21264163; this version posted January 1, 2022. The copyright holder for this preprint (which was not certified by peer review) is the author/funder, who has granted medRxiv a license to display the preprint in It is made available under a CC-BY-NC-ND 4.0 International license .

\section{Pseudovirus neutralization assay}

Neutralization activity was tested using a pseudovirus neutralization assay, as previously described $^{43}$. Shortly, HEK293T/ACE2 cells, kindly provided by Dr. Paul Bieniasz ${ }^{68}$, were seeded at a density of 20,000 cells/well in a 96 -well plate coated with $50 \mu \mathrm{g} / \mathrm{mL}$ poly-L-lysine one day prior to the start of the neutralization assay. Heat-inactivated sera samples $(1: 100$ dilution or 1:20 for Omicron) were serially diluted in cell culture medium (DMEM (Gibco), supplemented with 10\% FBS, penicillin $(100 \mathrm{U} / \mathrm{mL})$, streptomycin $(100 \mu \mathrm{g} / \mathrm{mL})$ and GlutaMax (Gibco)), mixed in a 1:1 ratio with pseudovirus and incubated for 1 hour at $37^{\circ} \mathrm{C}$. Subsequently, these mixtures were added to the cells in a 1:1 ratio and incubated for 48 hours at $37^{\circ} \mathrm{C}$, followed by a PBS wash and lysis buffer to measure the luciferase activity in cell lysates using the Nano-Glo Luciferase Assay System (Promega) and GloMax system (Turner BioSystems). Relative luminescence units (RLU) were normalized to the positive control wells where cells were infected with pseudovirus in the absence of NAbs or sera. The neutralization titers $\left(\mathrm{ID}_{50}\right)$ were determined as the serum dilution at which infectivity was inhibited by $50 \%$, respectively, using a non-linear regression curve fit (GraphPad Prism software version 8.3). Samples with $\mathrm{ID}_{50}$ titers $<100$ were defined as having undetectable neutralization.

\section{Visualization and statistical analysis}

Data visualization and statistical analyses were performed in GraphPad Prism software (version 8.3). The non-parametric Kruskal-Wallis test was performed for unpaired samples to compare antibody binding or neutralization titers between the different vaccine groups post first dose or full vaccination (for Ad26.COV2.S this was the same time point). The Spearman's rank correlation was performed for the comparison between median neutralization titer per vaccine group and reported vaccine efficacy. 
medRxiv preprint doi: https://doi.org/10.1101/2021.09.27.21264163; this version posted January 1, 2022. The copyright holder for this preprint (which was not certified by peer review) is the author/funder, who has granted medRxiv a license to display the preprint in It is made available under a CC-BY-NC-ND 4.0 International license .

\section{References}

1. https://covid19.who.int/.

2. Baden, L. R. et al. Efficacy and Safety of the mRNA-1273 SARS-CoV-2 Vaccine. N. Engl. J. Med. 384, 403-416 (2021).

3. Polack, F. P. et al. Safety and Efficacy of the BNT162b2 mRNA Covid-19 Vaccine. N. Engl. J. Med. 383, 2603-2615 (2020).

4. Sadoff, J. et al. Safety and Efficacy of Single-Dose Ad26.COV2.S Vaccine against Covid-19. N. Engl. J. Med. 384, 2187-2201 (2021).

5. Voysey, M. et al. Safety and efficacy of the ChAdOx1 nCoV-19 vaccine (AZD1222) against SARS-CoV-2: an interim analysis of four randomised controlled trials in Brazil, South Africa, and the UK. Lancet 397, 99-111 (2021).

6. Chemaitelly, H. et al. Waning of BNT162b2 Vaccine Protection against SARS-CoV-2 Infection in Qatar. N. Engl. J. Med. 385, e83 (2021).

7. Earle, K. A. et al. Evidence for antibody as a protective correlate for COVID-19 vaccines. Vaccine 39, 4423-4428 (2021).

8. Khoury, D. S. et al. Neutralizing antibody levels are highly predictive of immune protection from symptomatic SARS-CoV-2 infection. Nat. Med. 27, 1205-1211 (2021).

9. Cromer, D. et al. SARS-CoV-2 variants: levels of neutralisation required for protective immunity. medRxiv 2021.08.11.21261876 (2021). doi:10.1101/2021.08.11.21261876

10. https://covid19.who.int/.

11. https://covariants.org/.

12. Harvey, W. T. et al. SARS-CoV-2 variants, spike mutations and immune escape. Nat. Rev. Microbiol. 19, 409-424 (2021).

13. Sanders, R. W. \& de Jong, M. D. Pandemic moves and countermoves: vaccines and viral 
medRxiv preprint doi: https://doi.org/10.1101/2021.09.27.21264163; this version posted January 1, 2022. The copyright holder for this preprint (which was not certified by peer review) is the author/funder, who has granted medRxiv a license to display the preprint in It is made available under a CC-BY-NC-ND 4.0 International license.

variants. Lancet 397, 1326-1327 (2021).

14. Lopez Bernal, J. et al. Effectiveness of Covid-19 Vaccines against the B.1.617.2 (Delta) Variant. N. Engl. J. Med. 385, 585-594 (2021).

15. Thomas, S. J. et al. Safety and Efficacy of the BNT162b2 mRNA Covid-19 Vaccine through 6 Months. N. Engl. J. Med. (2021). doi:10.1056/NEJMoa2110345

16. Abu-Raddad, L. J., Chemaitelly, H. \& Butt, A. A. Effectiveness of the BNT162b2 Covid-19 Vaccine against the B.1.1.7 and B.1.351 Variants. N. Engl. J. Med. 385, 187-189 (2021).

17. de Gier, B. et al. COVID-19 vaccine effectiveness against hospitalizations and ICU admissions in the Netherlands, April- August 2021. medRxiv 2021.09.15.21263613 (2021). doi:10.1101/2021.09.15.21263613

18. Sheikh, A., McMenamin, J., Taylor, B. \& Robertson, C. SARS-CoV-2 Delta VOC in Scotland: demographics, risk of hospital admission, and vaccine effectiveness. Lancet 397, 2461-2462 (2021).

19. Cromer, D. et al. SARS-CoV-2 variants: levels of neutralisation required for protective immunity. medRxiv 2021.08.11.21261876 (2021). doi:10.1101/2021.08.11.21261876

20. Sadoff, J. et al. Safety and Efficacy of Single-Dose Ad26.COV2.S Vaccine against Covid-19. N. Engl. J. Med. 384, 2187-2201 (2021).

21. Madhi, S. A. et al. Efficacy of the ChAdOx1 nCoV-19 Covid-19 Vaccine against the B.1.351 Variant. N. Engl. J. Med. 384, 1885-1898 (2021).

22. Tada, T. et al. Comparison of Neutralizing Antibody Titers Elicited by mRNA and Adenoviral Vector Vaccine against SARS-CoV-2 Variants. bioRxiv 2021.07.19.452771 (2021). doi:10.1101/2021.07.19.452771

23. Planas, D. et al. Considerable escape of SARS-CoV-2 Omicron to antibody neutralization. Nature (2021). doi:10.1038/d41586-021-03827-2

24. Dejnirattisai, W. et al. Reduced neutralisation of SARS-CoV-2 omicron B.1.1.529 variant by 
medRxiv preprint doi: https://doi.org/10.1101/2021.09.27.21264163; this version posted January 1, 2022. The copyright holder for this preprint (which was not certified by peer review) is the author/funder, who has granted medRxiv a license to display the preprint in It is made available under a CC-BY-NC-ND 4.0 International license .

post-immunisation serum. Lancet (2021). doi:10.1016/S0140-6736(21)02844-0

25. Hoffmann, M. et al. The Omicron variant is highly resistant against antibody-mediated neutralization - implications for control of the COVID-19 pandemic. Cell (2021). doi:10.1016/j.cell.2021.12.032

26. Sikkens, J. J. et al. Serologic Surveillance and Phylogenetic Analysis of SARS-CoV-2 Infection Among Hospital Health Care Workers. JAMA Netw. Open 4, e2118554 (2021).

27. https://lci.rivm.nl/richtlijnen/covid-19-vaccinatie.

28. Wrapp, D. et al. Cryo-EM structure of the 2019-nCoV spike in the prefusion conformation. Science (80-. ). 367, 1260-1263 (2020).

29. Caniels, T. G. et al. Emerging SARS-CoV-2 variants of concern evade humoral immune responses from infection and vaccination. Sci. $A d v .7,(2021)$.

30. Earle, K. A. et al. Evidence for antibody as a protective correlate for COVID-19 vaccines. Vaccine 39, 4423-4428 (2021).

31. Khoury, D. S. et al. Neutralizing antibody levels are highly predictive of immune protection from symptomatic SARS-CoV-2 infection. Nat. Med. 27, 1205-1211 (2021).

32. Sanders, R. W. \& de Jong, M. D. Pandemic moves and countermoves: vaccines and viral variants. Lancet 397, 1326-1327 (2021).

33. Lopez Bernal, J. et al. Effectiveness of Covid-19 Vaccines against the B.1.617.2 (Delta) Variant. N. Engl. J. Med. 385, 585-594 (2021).

34. Thomas, S. J. et al. Safety and Efficacy of the BNT162b2 mRNA Covid-19 Vaccine through 6 Months. N. Engl. J. Med. (2021). doi:10.1056/NEJMoa2110345

35. Abu-Raddad, L. J., Chemaitelly, H. \& Butt, A. A. Effectiveness of the BNT162b2 Covid-19 Vaccine against the B.1.1.7 and B.1.351 Variants. N. Engl. J. Med. 385, 187-189 (2021).

36. de Gier, B. et al. COVID-19 vaccine effectiveness against hospitalizations and ICU admissions in the Netherlands, April- August 2021. medRxiv 2021.09.15.21263613 (2021). 
medRxiv preprint doi: https://doi.org/10.1101/2021.09.27.21264163; this version posted January 1, 2022. The copyright holder for this preprint (which was not certified by peer review) is the author/funder, who has granted medRxiv a license to display the preprint in It is made available under a CC-BY-NC-ND 4.0 International license .

doi:10.1101/2021.09.15.21263613

37. Sheikh, A., McMenamin, J., Taylor, B. \& Robertson, C. SARS-CoV-2 Delta VOC in Scotland: demographics, risk of hospital admission, and vaccine effectiveness. Lancet 397, 2461-2462 (2021).

38. Madhi, S. A. et al. Efficacy of the ChAdOx1 nCoV-19 Covid-19 Vaccine against the B.1.351 Variant. N. Engl. J. Med. 384, 1885-1898 (2021).

39. Baden, L. R. et al. Efficacy and Safety of the mRNA-1273 SARS-CoV-2 Vaccine. N. Engl. J. Med. 384, 403-416 (2021).

40. Voysey, M. et al. Safety and efficacy of the ChAdOx1 nCoV-19 vaccine (AZD1222) against SARS-CoV-2: an interim analysis of four randomised controlled trials in Brazil, South Africa, and the UK. Lancet 397, 99-111 (2021).

41. https://covariants.org/.

42. van Gils, M. J. et al. Single-dose SARS-CoV-2 vaccine in a prospective cohort of COVID-19 patients. medRxiv 2021.05.25.21257797 (2021). doi:10.1101/2021.05.25.21257797

43. Caniels, T. G. et al. Emerging SARS-CoV-2 variants of concern evade humoral immune responses from infection and vaccination. Sci. Adv. 7, (2021).

44. Harvey, W. T. et al. SARS-CoV-2 variants, spike mutations and immune escape. Nat. Rev. Microbiol. 19, 409-424 (2021).

45. Sadoff, J. et al. Interim Results of a Phase 1-2a Trial of Ad26.COV2.S Covid-19 Vaccine. $N$. Engl. J. Med. 384, 1824-1835 (2021).

46. Sanders, R. W. \& Moore, J. P. Virus vaccines: proteins prefer prolines. Cell Host Microbe 29, $327-333$ (2021).

47. Israelow, B. et al. Adaptive immune determinants of viral clearance and protection in mouse models of SARS-CoV-2. Sci. Immunol. (2021). doi:10.1126/sciimmunol.abl4509

48. Bertoletti, A., Le Bert, N., Qui, M. \& Tan, A. T. SARS-CoV-2-specific T cells in infection and 
medRxiv preprint doi: https://doi.org/10.1101/2021.09.27.21264163; this version posted January 1, 2022. The copyright holder for this preprint (which was not certified by peer review) is the author/funder, who has granted medRxiv a license to display the preprint in It is made available under a CC-BY-NC-ND 4.0 International license.

vaccination. Cell. Mol. Immunol. (2021). doi:10.1038/s41423-021-00743-3

49. Alter, G. et al. Immunogenicity of Ad26.COV2.S vaccine against SARS-CoV-2 variants in humans. Nature 596, 268-272 (2021).

50. Geers, D. et al. SARS-CoV-2 variants of concern partially escape humoral but not T-cell responses in COVID-19 convalescent donors and vaccinees. Sci. Immunol. 6, eabj1750 (2021).

51. Mateus, J. et al. Low dose mRNA-1273 COVID-19 vaccine generates durable T cell memory and antibodies enhanced by pre-existing crossreactive $\mathrm{T}$ cell memory. medRxiv 2021.06.30.21259787 (2021). doi:10.1101/2021.06.30.21259787

52. Goel, R. R. et al. Distinct antibody and memory B cell responses in SARS-CoV-2 naïve and recovered individuals following mRNA vaccination. Sci. Immunol. 6, eabi6950 (2021).

53. Dan, J. M. et al. Immunological memory to SARS-CoV-2 assessed for up to 8 months after infection. Science (80-. ). 371, eabf4063 (2021).

54. He, Q. et al. Heterologous prime-boost: breaking the protective immune response bottleneck of COVID-19 vaccine candidates. Emerg. Microbes Infect. 10, 629-637 (2021).

55. Liu, X. et al. Safety and immunogenicity of heterologous versus homologous prime-boost schedules with an adenoviral vectored and mRNA COVID-19 vaccine (Com-COV): a singleblind, randomised, non-inferiority trial. Lancet 398, 856-869 (2021).

56. Steensels, D., Pierlet, N., Penders, J., Mesotten, D. \& Heylen, L. Comparison of SARS-CoV2 Antibody Response Following Vaccination With BNT162b2 and mRNA-1273. JAMA (2021). doi:10.1001/jama.2021.15125

57. Rauch, S. et al. mRNA-based SARS-CoV-2 vaccine candidate CVnCoV induces high levels of virus-neutralising antibodies and mediates protection in rodents. npj Vaccines 6, 57 (2021).

58. Greaney, A. J. et al. Mapping mutations to the SARS-CoV-2 RBD that escape binding by different classes of antibodies. Nat. Commun. 12, 4196 (2021).

59. Wang, P. et al. Antibody resistance of SARS-CoV-2 variants B.1.351 and B.1.1.7. Nature 593, 
medRxiv preprint doi: https://doi.org/10.1101/2021.09.27.21264163; this version posted January 1, 2022. The copyright holder for this preprint (which was not certified by peer review) is the author/funder, who has granted medRxiv a license to display the preprint in It is made available under a CC-BY-NC-ND 4.0 International license.

130-135 (2021).

60. Starr, T. N. et al. Prospective mapping of viral mutations that escape antibodies used to treat COVID-19. Science (80-. ). 371, 850-854 (2021).

61. Liu, Y. et al. The SARS-CoV-2 Delta variant is poised to acquire complete resistance to wildtype spike vaccines. bioRxiv 2021.08.22.457114 (2021). doi:10.1101/2021.08.22.457114

62. Tada, T. et al. SARS-CoV-2 Lambda Variant Remains Susceptible to Neutralization by mRNA Vaccine-elicited Antibodies and Convalescent Serum. bioRxiv 2021.07.02.450959 (2021). doi:10.1101/2021.07.02.450959

63. Sikkens, J. J. et al. Serologic Surveillance and Phylogenetic Analysis of SARS-CoV-2 Infection Among Hospital Health Care Workers. JAMA Netw. Open 4, e2118554 (2021).

64. https://www.rivm.nl/coronavirus-covid-19/virus/varianten.

65. van Gils, M. J. et al. Single-dose SARS-CoV-2 vaccine in a prospective cohort of COVID-19 patients. medRxiv 2021.05.25.21257797 (2021). doi:10.1101/2021.05.25.21257797

66. Keuning, M. W. et al. Saliva SARS-CoV-2 Antibody Prevalence in Children. Microbiol. Spectr. (2021). doi:10.1128/Spectrum.00731-21

67. Keuning, M. W. et al. Saliva SARS-CoV-2 Antibody Prevalence in Children. Microbiol. Spectr. (2021). doi:10.1128/Spectrum.00731-21

68. Schmidt, F. et al. Measuring SARS-CoV-2 neutralizing antibody activity using pseudotyped and chimeric viruses. J. Exp. Med. 217, (2020).

\section{Acknowledgments}

We thank Dr. Paul Bieniasz and Theodora Hatziioannou of the Howard Hughes Medical Institute, Rockefeller University, New York, USA and Dr. Beatrice Hahn of the Perelman School of Medicine, University of Pennsylvania, Philadelphia, USA for donating cells and reagents for pseudovirus neutralization assays; Dirk Eggink and Chantal Reusken of the 
medRxiv preprint doi: https://doi.org/10.1101/2021.09.27.21264163; this version posted January 1, 2022. The copyright holder for this preprint (which was not certified by peer review) is the author/funder, who has granted medRxiv a license to display the preprint in It is made available under a CC-BY-NC-ND 4.0 International license .

National Institute for Public Health and the Environment, Bilthoven, the Netherlands for providing the SARS-CoV-2 B.1.617.2 S protein; Johan Reimerink, Fion Brouwer, Marieke Hoogerwerf and Tarek Munawar, Bas J. Verkaik, Orlane J.A. Figaroa, Peter J. de Vries, Tessel M. Boertien, Neeltje A. Kootstra and all researchers, nurses and students of the RECoVERED Study team for technical assistance; and all the participants of the S3/HCW, COSCA and RECoVERED studies.

\section{Funding}

This work was supported by the Netherlands Organization for Scientific Research (NWO) ZonMw (S3 study, grant agreement no. 10430022010023 to M.K.B.; RECoVERED, grant agreement no. 10150062010002 to M.D.d.J., and Vici grant no. 91818627 to R.W.S.), by the Bill \& Melinda Gates Foundation (grant no. INV002022 and INV008818 to R.W.S. and INV024617 to M.J.v.G.), by Amsterdam UMC through the AMC Fellowship (to M.J.v.G.) and the Corona Research Fund (to M.K.B.), and by the European Union's Horizon 2020 program (RECoVER, grant no. 101003589 to M.D.d.J). The funders had no role in study design, data collection and analysis, decision to publish, or preparation of the manuscript.

\section{Author contributions}

Conceptualization: M.J.v.G., J.J.S., M.K.B., R.W.S.; Funding acquisition: M.J.v.G., M.D.d.J., J.J.S., M.K.B., R.W.S.; Investigation: M.J.v.G., A.H.A.L., K.v.d.S., B.A., I.B., Me.P., J.A.B., M.O., K.T., J.H.B., M.G.; Methodology: M.J.v.G., J.J.S., M.K.B., R.W.S.; Project administration: M.J.v.G., A.H.A.L., K.v.d.S., B.A., J.J.S., M.K.B.; Resources: M.A.S., M.S., L.A.V., E.W., H.D.G.v.W., M.G., J.S., T.G.C., S3/HCW, A.P.J.V., M.D.d.J., G.J.d.B.; Supervision: M.J.v.G., A.P.J.V., Ma.P., M.D.d.J., G.J.d.B., J.J.S., M.K.B., R.W.S.; Writing original draft: M.J.v.G., R.W.S.; Writing - review \& editing: all authors. 
medRxiv preprint doi: https://doi.org/10.1101/2021.09.27.21264163; this version posted January 1, 2022. The copyright holder for this preprint (which was not certified by peer review) is the author/funder, who has granted medRxiv a license to display the preprint in It is made available under a CC-BY-NC-ND 4.0 International license .

\section{Competing interests}

Amsterdam UMC filed a patent application on SARS-CoV-2 monoclonal antibodies including the ones used in this manuscript.

\section{Data and materials availability}

All data are available in the main text or supplementary materials. Reagents used in this study are available upon reasonable request under an MTA with Amsterdam UMC. 
medRxiv preprint doi: https://doi.org/10.1101/2021.09.27.21264163; this version posted January 1, 2022. The copyright holder for this preprint (which was not certified by peer review) is the author/funder, who has granted medRxiv a license to display the preprint in It is made available under a CC-BY-NC-ND 4.0 International license.
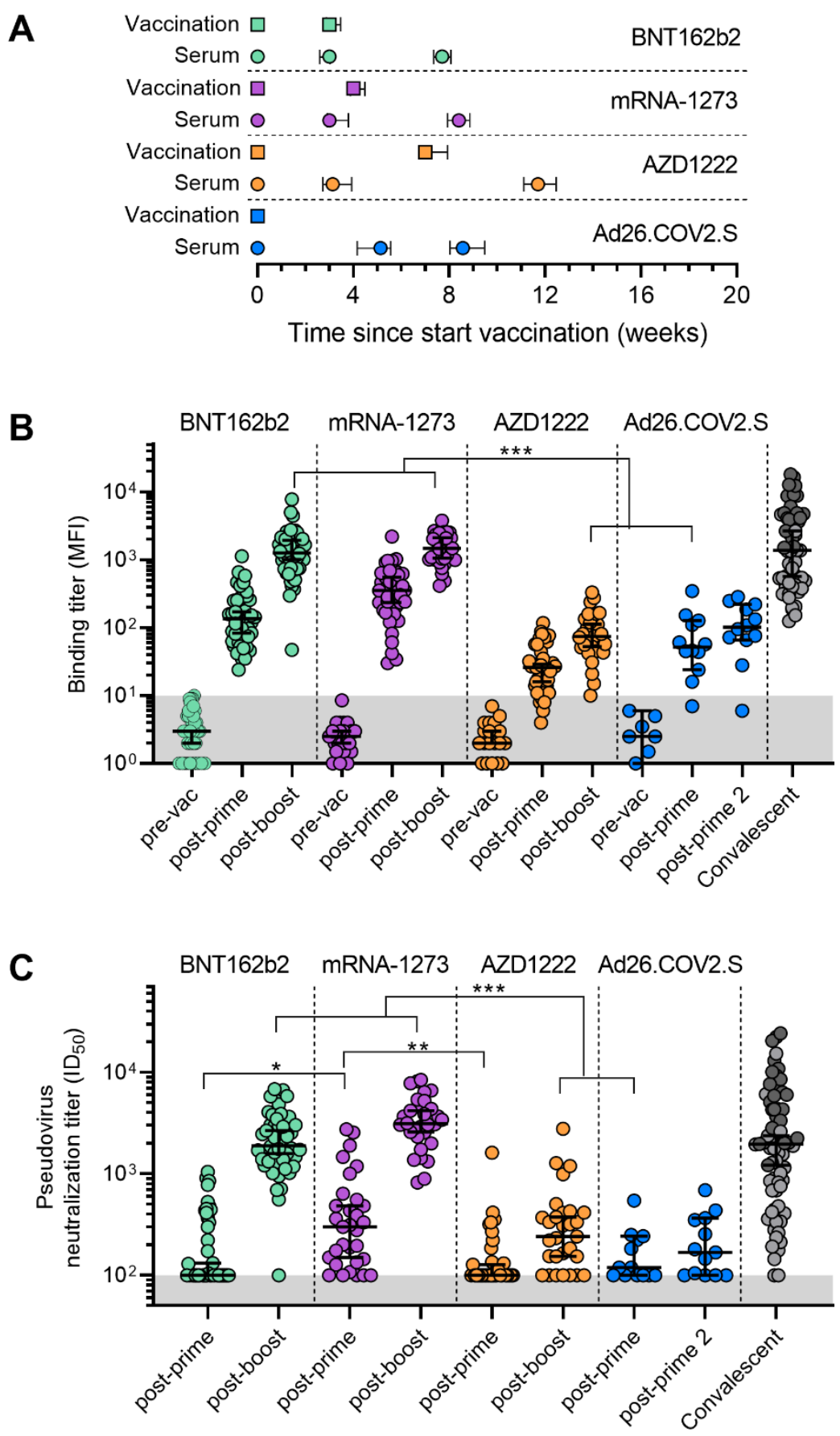

Figure 1: Binding and neutralization titers pre- and post-vaccination with one of the four SARS-CoV-2 vaccines. (A) Timelines of the vaccinations and serum collections, showing the mean and interquartile range of times of vaccination and samples in weeks after the first dose. (B) Binding titers to wild-type S protein represented as mean fluorescence intensity (MFI) of $1: 100,000$ diluted sera collected pre- and post-vaccination for the four vaccination groups. The convalescent group $(n=68)$ consists of sera from hospitalized (dark gray) and non-hospitalized (light gray) COVID-19 patients collected 4-6 weeks post symptom onset. Median and 95\% confidence intervals are indicated. The lower cutoff for binding was set at an MFI of 10 (grey shading). (C) Median half-maximal neutralization (ID 50 ) titers of D614G pseudovirus for sera collected post-vaccination for the four vaccination groups. The convalescent group $(n=68)$ 
medRxiv preprint doi: https://doi.org/10.1101/2021.09.27.21264163; this version posted January 1, 2022. The copyright holder for this preprint (which was not certified by peer review) is the author/funder, who has granted medRxiv a license to display the preprint in It is made available under a CC-BY-NC-ND 4.0 International license .

consists of sera from hospitalized (dark gray) and non-hospitalized (light gray) COVID-19 patients collected 4-6 weeks post symptom onset. Median and $95 \%$ confidence intervals are indicated. The lower cutoff for neutralization was set at an $\mathrm{ID}_{50}$ of 100 (grey shading). All data points shown here represent the mean of a technical triplicate. ${ }^{*}, p<0.01, * *, p<0.001, * * *$, $p<0.0001$. 

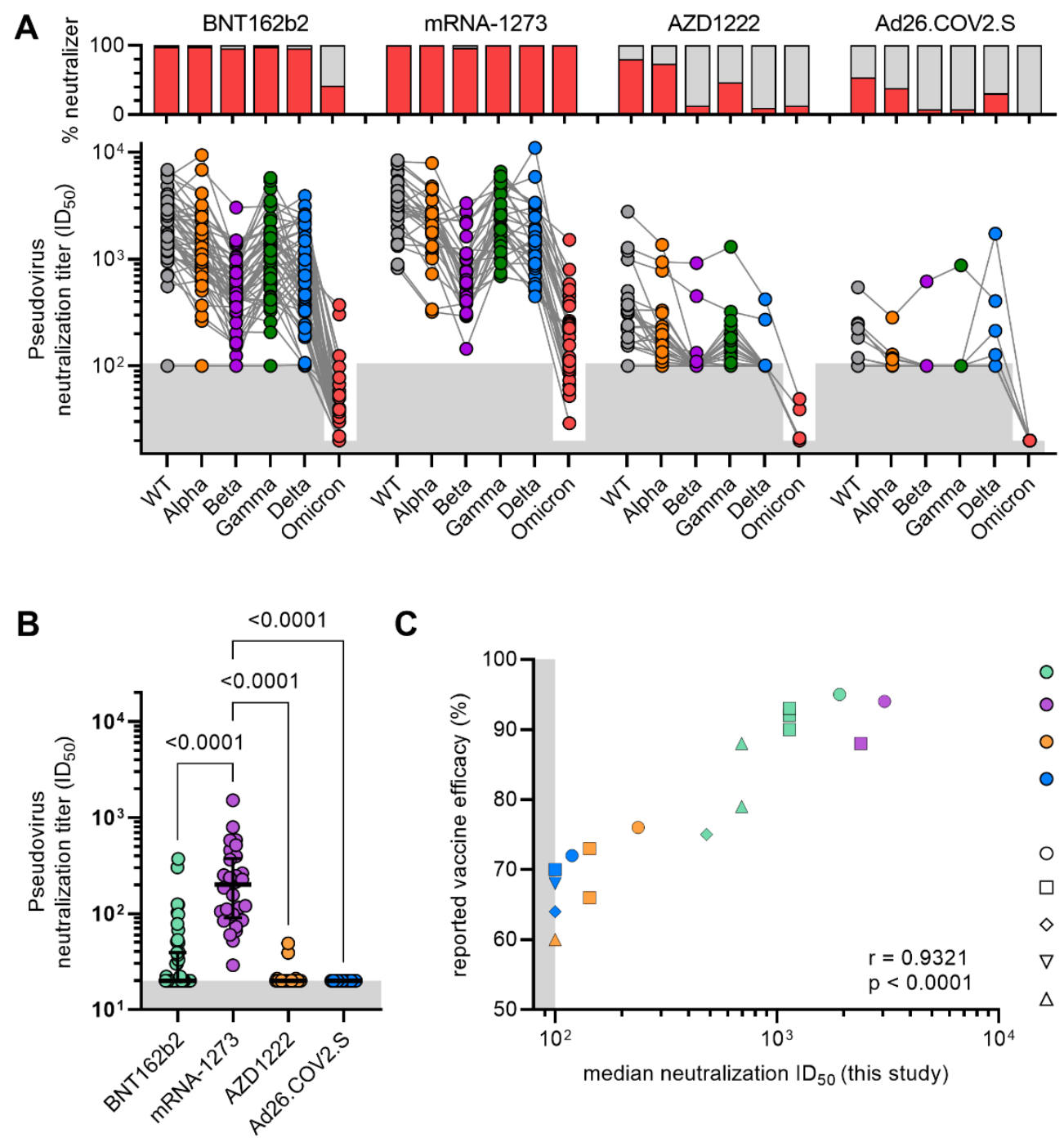

C

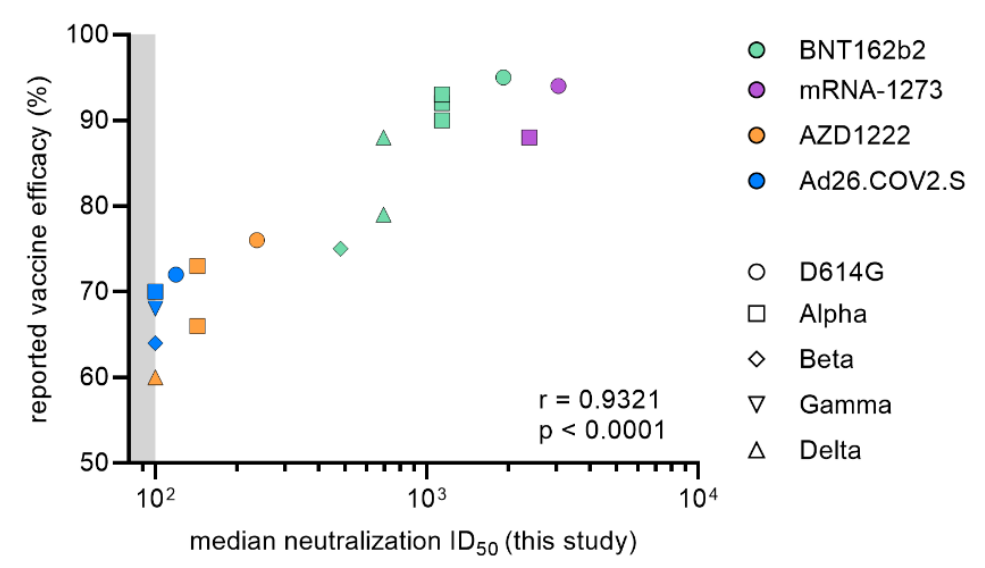

Figure 2: Binding and neutralization titers post-vaccination against VOCs. (A) Paired half-maximal neutralization (ID 50 ) titers of D614G and VOCs pseudoviruses for sera collected post vaccination for the four vaccination groups (lower panel). The lower cut-off for neutralization was set at an $\mathrm{ID}_{50}$ of 100 or 20 (grey shading). Percentage vaccine recipients with detectable neutralization titers in red (upper panel). (B) Neutralization titers of Omcrion pseudovirus for sera post vaccination. (C) Median $\mathrm{ID}_{50}$ neutralization of D614G and VOCs plotted against the reported vaccine efficacy against symptomatic infection ${ }^{3,20,33-40}$. Vaccine groups are indicated by colors with BNT162b2 in green, mRNA-1273 in purple, AZD1222 in orange and Ad26.COV2.S in blue. Circles represent WT data, squares for Alpha, diamond for Beta, nabla triangle for Gamma and delta triangle for Delta. Spearman's rank correlation coefficient with $p$ value are indicated. The result of the AZD1222 phase 3 trial conducted in South Africa, demonstrating poor (10\%) efficacy against Beta variant, is not shown. 
medRxiv preprint doi: https://doi.org/10.1101/2021.09.27.21264163; this version posted January 1, 2022. The copyright holder for this preprint (which was not certified by peer review) is the author/funder, who has granted medRxiv a license to display the preprint in It is made available under a CC-BY-NC-ND 4.0 International license .

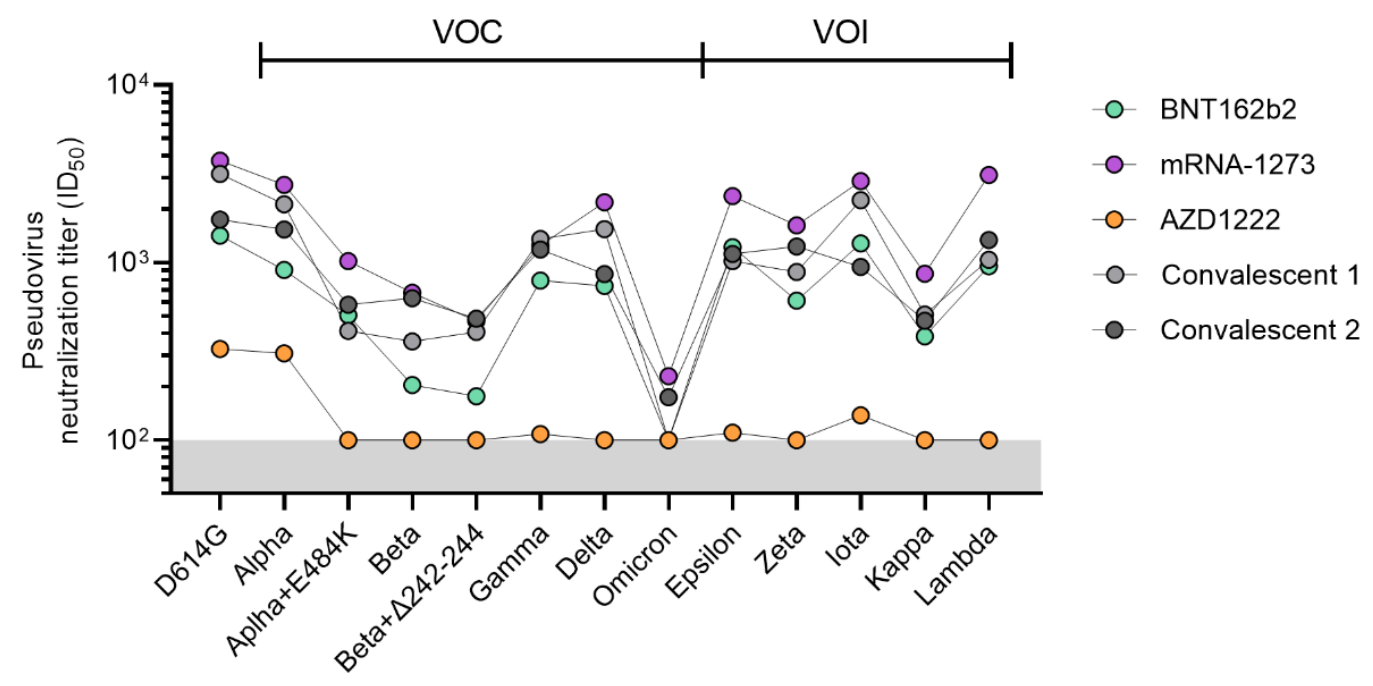

Figure 3: Neutralization titers of pooled sera against VOCs and VOIs. Half-maximal neutralization ( $\left.\mathrm{ID}_{50}\right)$ titers of SARS-CoV-2 variant pseudoviruses for pooled sera for the vaccination groups (excluding the Ad26.COV2.S group) after full vaccination. The lower cutoff for neutralization was set at an $\mathrm{ID}_{50}$ of 100 (grey shading). Convalescent group 1 (light gray) consists of pooled COSCA sera representing COVID-19 patients between 4-6 weeks post symptom onset and convalescent group 2 (dark gray) consists of pooled RECoVERED sera representing COVID-19 patients up to seven months post symptom onset (median three months), who experienced mild to severe COVID-19. Vaccine groups are indicated by colors with BNT162b2 in green, mRNA-1273 in purple and AZD1222 in orange. All data points shown here represent the mean of a technical triplicate and at least two replications. 
medRxiv preprint doi: https://doi.org/10.1101/2021.09.27.21264163; this version posted January 1, 2022. The copyright holder for this preprint (which was not certified by peer review) is the author/funder, who has granted medRxiv a license to display the preprint in It is made available under a CC-BY-NC-ND 4.0 International license .

\section{Table 1. Sociodemographic characteristics}

\begin{tabular}{|lllll|}
\hline \multirow{2}{*}{$\begin{array}{l}\text { Sociodemographic } \\
\text { Characteristics }\end{array}$} & BNT162b2 & mRNA-1273 & AZD1222 & Ad26.SARSCOV2.S \\
& $\mathrm{n}=50$ & $\mathrm{n}=40$ & $\mathrm{n}=41$ & $\mathrm{n}=13$ \\
\hline Sex & & & & \\
Male & $19(38 \%)$ & $5(13 \%)$ & $6(15 \%)$ & $2(15 \%)$ \\
Female & $31(62 \%)$ & $35(87 \%)$ & $35(85 \%)$ & $11(85 \%)$ \\
\hline Age in years & & & & \\
$<35$ & $14(28 \%)$ & $20(50 \%)$ & $0(0 \%)$ & $3(23 \%)$ \\
$35-60$ & $32(64 \%)$ & $20(50 \%)$ & $14(34 \%)$ & $9(69 \%)$ \\
$>60$ & $4(8 \%)$ & $0(0 \%)$ & $27(66 \%)$ & $1(8 \%)$ \\
\hline
\end{tabular}

